\title{
IX CONGRESS OF THE LATVIAN SOCIETY OF GENETICISTS AND BREEDERS
}

Latvian Society of Geneticists and Breeders was founded in 1966 as a part of the All-Union Society of Geneticists and Breeders. Since 1991, the Latvian Society operated as an independent unit. Once in six years, congresses of the Society are organised. The most recent IX Congress was held on 15-16 July 2016. The main task of the Congress was to make an overview of the Society's work since the previous Congress and have a look at the current situation in the genetic investigations and breeding work in Latvia, as well as the election of the new president and members of the Management Board of the Society for the next period.

Activities of the first day of the Congress were held in Riga, in the Institute of Food Safety, Animal Health and Environment (BIOR). The Congress started with a report of the President of the Society Izaks Rašals (Isaak Rashal) which was followed by several review presentations. Aivars Bērziņ̌̌ reported about the research directions of BIOR with a particular emphasis on investigations in molecular epidemiology of infections. Jānis Kloviṇš reported about achievements of the Latvian Biomedical Research and Study Centre (BMC) in human genetics and molecular medicine. Aigars Dzalbs presented data about practical aspects of medicinal genetics in Latvia. The presentation of Dace Grauda was devoted to theoretical and practical aspects of plant ploidy. Arta Kronberga acquainted the audience with new challenges in plant breeding in Latvia. Daina Kairiša's presentation was about the current situation in Latvian livestock genetic resources and researches in this area. Results of concrete genetic investigations and breeder achievements of Latvian scientists were presented in more than twenty posters.

On the next day, the participants of the Congress visited the Aquaculture Research and Study Centre of the Institute BIOR, located in the territory of the hatchery "Tome". The head of the centre Mārcis Zingis informed about the activities of the centre and hatchery, including about restoring fish genetic resources.

For the next period, İzaks Rašals (Isaak Rashal) was again elected as the president of the Latvian Society of Geneticists and Breeders, Nils Rostoks — as vice-president, Dace Grauda — as the scientific secretary.

The Latvian Society of Geneticists and Breeders included as members researchers and students from all corresponding universities and research and breeding institutions of Latvia. The Society is presented in several official bodies responsible for the country politics regarding GMO, genetic resources etc. The Society is active in organisation of different type scientific meetings on the national and international level. By the initiative of the Society, Baltic Genetics Congresses are organised periodically in all Baltic States. Next VII Baltic Genetics Congress will be held in Riga in 2018. The Society takes active part in the preparation of International Baltic Genetic Symposium which is planned in Riga in 2020 .

Information about the activities of the Latvian Society of Geneticists and Breeders can be found on www.lgsb.lv. 


\section{ABSTRACTS OF POSTER PRESENTATIONS}

A1

\section{ANALYSIS OF SCRAPIE GENOTYPE OF LATVIAN DARKHEAD SHEEP}

\section{Dace Bārzdiṇa, Daina Kairiša}

Institute of Agrobiotechnology, Faculty of Agriculture, Latvia University of Agriculture, LATVIA

dace.barzdina@llu.Iv, daina.kairisa@llu.Iv

Out of sheep breeds in Latvia, Latvian Darkhead (further LD) belong to the mutton-wool type, and LD meat production is important in Latvia. Local animals have strong constitution and ability to pass down the vitality to their progeny. Therefore, we maintain that LD sheep breed can serve as a genetic reserve for sheep population diversity. In order to identify the predisposition of sheep to lethal diseases, like scrapie in Europe, animal's blood sample analysis should be carried out for several years. In a Latvian study, blood sample analysis for this disease have been carried out for more than five years (Bārzdiṇa and Kairiša, 2013). Just like Bovine Spongiform Encephalopathy (BSE), and CreutzfeldtJakob disease (CJD) in human beings, in case of sheep (Ovis aries) and goats (Capra aegagrus hircus) scrapie (chesmus ovium) disease belongs to Transmissible Spongiform Encephalopathy (TSE) group. There are few studies on scrapie genotypes in LD breed. In order that Latvian sheep breeders be informed about the predisposition of the sheep in their herd to classical scrapie, from 2012 to 2015, the association "Latvian Association of Sheep Breeders" in cooperation with German partner EUROFINS Medigenmix laboratory, basing on blood samples, determined genotypes of classical scrapie in 8570 LD sheep and 640 breeding rams from 42 Latvian breeding farms. Animals which are most resistant to classical scrapie and which can be used for population breeding are included into haplogenic combination ALRR risk group R1. Animals which belong to haplogenic combination VLRQ risk group R5 are not allowed to be used for population breeding (Groschup et al., 2007). To get an idea of LD breed animal scrapie changes in the fiveyear period, the results of ewes and breeding rams were summarised. The compiled results show that the most common gene combination in LD ewes is R2, and animals of this gene class tended to decrease in 2015. Scrapie resistant gene combination R1 increases every year, and in 2012 the gene combination of the number of animals amounted to $22.0 \%$, but in 2015 it was already $32.1 \%$, which is an increase by $10.1 \%$. It was observed that the number of animals of R3, R4, and R5 gene combinations decreases every year what is a positive trend. The compiled results show that the most common gene combination of LD breeding rams is R2, and the number of animals with this gene combination in 2014 tended to decrease, but in 2015 the proportion was $46.2 \%$. The highest number of animals with scrapie resistant gene combinations R1 was observed in 2014, but in 2015 the proportion of animals amounted to $29.1 \%$.
A positive trend was observed in R4 and R5 gene combinations in 2015, where the gene combination of the number of animals had fallen, which can be explained by the fact that the owners understand the contagion of this disease. According to the genotyping results for occurring scrapie in LD sheep ewes and breeding rams, the most widespread gene combination for sheep $(41.0 \%)$ and breeding rams (42.3\%) was ALRR/ALRQ (R2 risk group). Gene combination ALRR/ALRR of the resistant group (R1) was found only in $24.0 \%$ of sheep and $31.1 \%$ of breeding rams from the LD breed. The most common combination in R3 risk group from the analysed LD sheep (20.3\%) and breeding rams $(16.9 \%)$ was ALRQ/ALRQ. The number of LD sheep and rams having the desirable scrapie genotype (R1 and R2) and the number of sheep and rams having the undesirable (R3-R5) scrapie genotype have decreased in herds during 10 years.

\section{REFERENCES}

Bārzdina, D. Kairiša, D. (2013). In Latvia bred of sheep breeds ewes scrapie genotype analysis. Proceedings of the Scientific and Practical Conference “Harmonious Agriculture”. Jelgava, Latvia, pp. 198-203.

Groschup, M. H., Lacroux, C., Buschmann, A. et al. (2007). Emerging Infectious Diseases, 13, 1201-1207.

\section{A2}

\section{RESEARCH RESULTS OF GENETIC RESOURCES FOR USE IN LATVIAN SPRING BARLEY BREED- ING PROGRAMME}

\author{
Māra Bleidere ${ }^{1}$, Igor Loskutov ${ }^{2}$, and Ilze Grunte ${ }^{1}$ \\ ${ }^{1}$ Stende Research Centre, Institute of Agricultural Resources and \\ Economics, LATVIA, maara.bleidere@gmail.com \\ ${ }^{2}$ N. I. Vavilov Institute of Plant Genetic Resources, St. Petersburg, \\ RUSSIA, i.loskutov@vir.nw.ru
}

Barley (Hordeum vulgare L.) is the main feed crop in Latvia, though it is also used for human consumption. Since malt production factory is built in Latvia there is restored interest in malting barley, too. The use of highly diverse germplasm in breeding increases the chances for success in developing highly productive new varieties with good quality properties. Plant breeders traditionally base breeding programmes on working or breeders' collections of carefully selected genotypes of a given crop that possess useful traits for incorporation into an adapted variety. Collecting, evaluation, and using of genetic resources in plant breeding started since the foundation of breeding work. Therefore, these collections tend to be dynamic and are modified according to needs. Collections of barley at the N. I. Vavilov Institute of Plant Genetic Resources (VIR, Russia) that are among the largest in Europe serve as a valuable source providing new initial material to breeding programmes. The 
aim of this research was to evaluate the phenotypic diversity of spring barley estimating their potential usefulness for breeding in Latvia. The results facilitate a better understanding of the diversity level of barley material with different origin and their performance under Latvian agro-ecological conditions.

The agronomic assessment of yield and grain quality was conducted at the State Stende Cereal Breeding Institute (today Stende Research Centre, Institute of Agricultural Resources and Economics), in 2013-2015, including 93 hulled spring barley accessions from N. I. Vavilov Institute of Plant Genetic Resources (VIR), originated from 29 countries. Genotypes were grown on $1 \mathrm{~m}^{2}$ plots in two replications by $85 \mathrm{~kg} \cdot \mathrm{ha}^{-1}$ of $\mathrm{N}, \mathrm{P}, \mathrm{K}$, respectively. Growing conditions: well-cultivated moraine loamy sand soil with $\mathrm{pH}_{\mathrm{KCl}}$ of 5.8-6.1 in arable layer, $18-24 \mathrm{~g} \cdot \mathrm{kg}^{-1}$ organic matter. Sowing and harvesting were performed in optimal terms. 1000 kernel weight (TKW, g) was evaluated by ISTA method. Macronutrients crude protein content $\left(\mathrm{g} \cdot \mathrm{kg}^{-1}\right)$, starch content $\left(\mathrm{g} \cdot \mathrm{kg}^{-1}\right), \beta$-glucans content $\left(\mathrm{g} \cdot \mathrm{kg}^{-1}\right)$ were analysed by Infratec Analysis 1241. Plant morphological and phenological traits were assessed; resistance to lodging (1-9 scores) and diseases (Blumeria graminis, Drechslera teres; 0-4 scores) were investigated. The results of statistical analyses showed that barley genotypes differed significantly in all characters under study. The average grain yield during the three years ranged from 1.67 to $8.75 \mathrm{t} \cdot \mathrm{ha}^{-1}$ (local standard 'Ansis' $6.27 \mathrm{t} \cdot \mathrm{ha}^{-1}$ ) where genotype determined $60 \%$ of this trait dispersion. Most productive varieties were 'Onslow', 'Tallon', 'Franklin' (Australia), 'Gavotte', 'Barleta' (France) showing the yield more than $8.0 \mathrm{t} \cdot \mathrm{ha}^{-1}$. The variation of TKW was mainly due to genotype $\left(\omega^{2}=89 \%\right)$; this trait among barley genotypes varied from 33.4 to $61.8 \mathrm{~g}$. Very coarse grains (TKW above $55 \mathrm{~g}$ ) constantly provided the following varieties 'Medicum 223', 'Mironovskij 86', 'Galaktik' (Ukraine), 'Barleta' (France). The difference between minimum and maximum value of average crude protein was high and varied from 94.3 to $179.3 \mathrm{~g} \cdot \mathrm{kg}^{-1}$. The highest crude protein content (above $15.5 \mathrm{~g} \cdot \mathrm{kg}^{-1}$ ) was observed for barley genotypes Unnamed/VIR Catalogue No 15591 (Chine), 'Kitaki-hadaka', Shiro-hadaka (Japan), Abian (Mexico). According to research results 17 hulled spring barley genotypes with heightened $\beta$-glucans content (above $50 \mathrm{~g} \cdot \mathrm{kg}^{-1}$ ) were identified such as 'S-128' (Mexico), Unnamed/VIR Catalogue No 12175 (Chine). Weak resistance to lodging (below 5 scores) was detected for 31 spring barley genotypes, therefore pre-breeding research potentially will be required to eliminate such a negative impact. Under Latvia's conditions, higher grain yield showed spring barley genotypes with good resistance to lodging and later rate of development. According to the correlation analysis, high yielding varieties characterized with heightened TKW and reduced crude protein content. Overall the VIR collection which was evaluated under Latvian conditions contains interesting hulled spring barley initial material meeting various breeding requirements.
A3

\section{GENETIC DIFFERENTIATION OF PERCH POPULA- TIONS FROM LATVIAN AND LITHUANIAN RESER- VOIRS}

Oksana Fokina, Dace Grauda, and Isaak Rashal

Institute of Biology, University of Latvia, LATVIA

oksana.fokina@lu.Iv

Wild Eurasian perch, or Redfin perch (Perca fluviatilis), is a freshwater predatory species and has a reputation as a voracious predator, and it is native to Eurasia. Perca fluviatilis is one of the most common fish species in Latvia coastal and inner waters. It is a popular sport fish and at the same time also very useful in commercial aquaculture, thereby it has been widely introduced in such regions as Australia, New Zealand, and South Africa. The goal of this study was to detect the level of genetic diversity of perch populations in nine Latvian and Lithuanian inner water reservoirs. Analysis of genetic diversity was based on iPBS technique (Kalendar et al., 2010), three retrotransposon-based unique primers were applied. Each of the three primers revealed more than 90 per cent of polymorphic loci regarding all analysed populations, and the total number of all found loci exceeded 120. Principal coordinates analysis was based on genetic distance matrices and was generated using NTSYS software. According to the obtained dendrogram nine studied populations were clustered in four groups. The closest genetic similarity was detected among two Latvian lakes (Babītes and Kāla) and the Lithuanian Nemunas River and Lake Plateliai. Another group was construed from two Latvian (Sventes and Engures) and two Lithuanian (Drūkšiai and Metelys) lakes. The separate cluster was formed by the single Latvian lake — Lake Cīrišs.

\section{A4 \\ GENETIC DIFERENCES IN SILVER BIRCH QUAL- ITY}

Arnis Gailis, Imants Baumanis, Endijs Baders, Mārtiņš Puriņš, and Āris Jansons

Latvian State Forest Research Institute "Silava", LATVIA

arnisg@silava.Iv

Birch (Betula pendula and Betula pubescens) cover almost one-third of Latvia's forest area according to the data of the National Forest Inventory. The monetary value of a birch stand is to a large extent determined by the amount (proportion) of veneer logs that can be obtained from it. The aim of our study was to assess the genetically determined difference in quality traits of silver birch as the basis for future analysis of economic feasibility of breeding (i.e. investment in breeding, plant production, and planting) of this tree species with abundant natural regeneration. 
Quality traits were assessed in three levels - clone, open pollinated family, and provenance. Analysis of data from trial at the age of 40 years ( 31 grafted birch plus-tree) reveal that clone has a significant effect on all traits characterising productivity (heritability for height and diameter: $h^{2}=0.14$ and $\mathrm{h}^{2}=0.21$, respectively), quality (for branch traits $\mathrm{h}^{2}=$ 0.14-0.33) and defects (e.g., stem cracks). Analysis of data from an open-pollinated progeny trial at the age of 14 years (100 families) reveal that the height up to the first green branch (determining the length of the stem section, where natural pruning had begun), the number of dry branches in first two meters (characterizing the speed of natural pruning) as well as tree diameter (describing the potential speed of healing-over of branch wounds) had high heritability: $\mathrm{h}^{2}=0.33, \mathrm{~h}^{2}=0.27$ and $\mathrm{h}^{2}=0.45$ (without competition as covariate: 0.20 ), respectively. Tree diameter had a positive and significant genetic correlation with the height up to the first green branch $(\mathrm{r}=0.64, p<0.001)$ and a negative but not significant correlation with the number of branches in the first two metres of stem $(r=-0.11)$; a respective correlation between tree height and branch traits was similar $(\mathrm{r}=$ $0.56, p<0.001$ and $r=-0.26, p<0.01)$. To conclude: there was a high potential of improving the natural pruning of trees and selection based on growth traits (height or diameter) would also result in better branch quality of silver birch. Phenotypic differences in the quality of birch from different regions of Latvia had been found in previous studies. We assessed the differences between provenances (defined in this case as set of phenotypically selected plus trees from one or neighbouring stands) based on the data from three trials, altogether including open-pollinated families from 914 silver birch trees. A significant effect of provenance both on tree height and branch quality at the age of 14 years was found. Notable differences could be found both between provenances located relatively far apart as well as between neighbouring provenances, stressing the need for careful evaluation of the potential seed source (instead of reliance on some mean estimate of birch quality in the region), if planning natural regeneration. Also a high heritability and genetic variation of quality traits as well as genetic correlation to tree height suggests a notable potential to improve the birch quality, and consequently also the stem value, via breeding.

The study was funded by the project "Forest tree breeding for establishment of high genetic quality stands".

\section{A5 \\ FLOW CYTOMETRY FOR IDENTIFICATION OF CELLULAR CHANGES}

Dace Grauda, Inta Belogrudova, Anton Kolodinski, Jekaterina Voskresenska, Lada Bumbure, and Isaak Rashal

Institute of Biology, University of Latvia, LATVIA

dace.grauda@lu.lv

Currently sustainable ecological studies of urban environment are among the most popular and fast growing natural research fields in the world. All organisms, including plants, grown in urban areas are subject to the influence of different types, of ill-disposed pollution agents that cause a damaging effect on cells. Low frequency (50-60 HZ) electromagnetic field, UV irradiation and $\mathrm{SiO}_{2}$ nanoparticles (in the form of dust) are some of the agents that impact organisms on the cellular level. Thus, to find and understand all the changes that the pollution agents cause in cells, there must be a powerful investigation method that works on the cellular level as well. Such a method is flow cytometry - a biophysical technology employed in cell counting, cell sorting, biomarker detection, and protein engineering. Flow cytometry works through suspending cells in a stream of special fluid, exciting them by laser light and passing them through a detection device. It allows making multiparametric (up to 20 parameters) analysis of thousands of cells per second. In urban ecology studies flow cytometry is used to determine cell ploidy and gender, to sort a living cell from an apoptotic one, using fluorescent nanoparticles, and to detect an impact of various factors on cells by examining cell self-fluorescence. BD FACSJazz ${ }^{\circledR}$ cell sorter (BD Biosciences, USA) with flow cytometer function was used to measure the relative fluorescence of plant cells. For cell excitation the $488 \mathrm{~nm}$ Coherent Sapphire Solid State (blue) laser was used. Cells' relative fluorescence was measured at $530 \mathrm{~nm}$ and $585 \mathrm{~nm}$. The information of mean fluorescence intensity from the purified cell suspension samples was recorded. Preliminarily, multiple gate sizes and shapes were tested to find the one with the lowest CV. Using flow cytometer BS FACS Software 1.0.0.650 cells plot was created to determine the densest part that was later gated using oval-shaped gate. The gate included from 95 to $99 \%$ of all target cells. Our experience showed that the flow cytometry is an excellent method to define cell changes impacted by diverse factors. The main results in experiments using flow cytometry are listed below.

1. A significant increase in relative cell fluorescence was observed after incubation in $\mathrm{SiO}_{2}$ nanoparticles (SiNPs) suspension for several plant species: immature pollen cells of lime trees (Tillia cordata), cyclamen (Cyclamen persicum), wheat (Triticum aestivum), barley (Hordeum vulgare), somatic cells of flax (Linum usitatissimum). 
2. Addition of SiNPs of size 10-20 nm could cause an increase of cells oxidative stress that in turn cause an increase of the relative fluorescence of cells.

3. All cells exposed to low-frequency electromagnetic field at the presence of SiNPs had a decrease of relative cell fluorescence. It is possible that SiNPs formed conglomerates that affect cells as stress inhibitors.

4. A significant linkage of trees' growing conditions and the relative fluorescence increasing or decreasing were observed: the young pollen cells of greenhouse-grown trees were more sensitive to both factors (SiNPs and UV irradiation) than trees grown in the urban area of Riga.

5. The lime trees grown for a long time in the urban area had complex adaptability to a changeable environment.

\section{A6}

\section{CREATION AND CHARACTERISTICS OF ALFALFA CULTIVAR 'SK RASA'}

Aldis Jansons, Biruta Jansone, Sarmīte Rancāne, Aija Rebāne, and Gaḷina Jermuša

Institute of Agriculture, Latvia University of Agriculture, LATVIA aldisjan@ @vnet.lv

Alfalfa is one of the most common fodder legumes suitable for growing in agro-ecological conditions found in Latvia. In mixtures with perennial grasses it is used for production of summer and winter forage. Almost 20 years of purposeful work done by the breeders has led to the creation of a new alfalfa variety 'SK Rasa'. It has successfully passed all official examinations of variety and in 2015 it was registered and included in the Latvian and EU common catalogue of plant varieties. Breeding of alfalfa cultivar 'SK Rasa' started in 1996 in the Research Institute of Agriculture. Soil characteristic: sod podzolic, weakly acidic $(\mathrm{pH}$ $\mathrm{KCl}$ 5.8-6.2) with calcareous subsoil, humus content $1.8-2.0 \%$. Having studied alfalfa variety collection with a wide range of geographical origins, samples were selected according to the criteria of a new breed model: good growth intensity, winter hardiness, plasticity, high forage, and seed yield, etc. Overcoming extreme wintering conditions and the drought during the growing season, several varieties from different countries with previously mentioned economically valuable properties stood out in our agro-climatic conditions. Also one perspective number established in Skriveri conformed to numerous criteria stated. Then the varieties and numbers selected in isolated conditions were freely pollinated obtaining hybrid seed material. Subsequent progeny tests by repeated individual and family selection resulted in the creation of a hybrid population with the necessary properties. Alfalfa variety 'SK Rasa' is tetraploid, and it belongs to the blue lucerne species ( $M$. sativa $\mathrm{L}$.) characterized by dark violet flowers and seed pod with 3-4 turns. The flowers are arranged in clusters on stem or side branch tops. Inflorescence can have up to 20 flowers. First bloom the lower flower clusters of the main stem, then the upper ones. Flowering continues for almost a month. Alfalfa flower structure is complex, it cannot be receptive to their pollen, alfalfa is a cross-pollinated plant. After the flower pollination 3-4 turn spiral pod develops, containing 3-7 seeds. If pollination has not taken place, all the flowers fall off and no spirals are formed. Alfalfa 'SK Rasa' seeds can be kidney-shaped and heart-shaped with slightly greenish, yellow to light brown shade (depending on harvest conditions). Weight of 1000 seeds ranges from 1.7 to $2.3 \mathrm{~g}$. Variety 'SK Rasa' like all alfalfa plants is a warmth-loving crop, and an optimum temperature for seed germination is $18-20{ }^{\circ} \mathrm{C}$. Intensive spring growth begins when the average daily air temperature is above $+10{ }^{\circ} \mathrm{C}$, but for a good seed yield active temperature sum should be close to $2000{ }^{\circ} \mathrm{C}$. The variety is drought-tolerant, but it likes humidity for the production of high dry matter yield. 'SK Rasa' is a light-loving plant, since light is especially required for generative organs formation. In good light conditions they develop better when grown without cover crop. 'SK Rasa' is a medium early, relatively fast growing variety. In the agro-climatic conditions of Latvia usually 3-4 harvests of green fodder can be obtained. For better wintering it is important to allow once per season to reach gemmation - beginning of flowering phase. Under favourable growing conditions variety can remain in swards for 4-6 years. The variety is suitable for formation of highly productive swards in pure sowings or mixed with early grass varieties (timothy, meadow fescue, hybrid ryegrass, etc.). The variety is characterised by good winter hardiness. The length of the growing season from the beginning of regrowth to flowering is 55 to 60 days, the next mowings can be collected in approximately 40 days. The variety 'SK Rasa', like other alfalfa varieties is not recommended to be mown in September, when alfalfa roots intensively accumulate nutrient reserves for successful wintering. Seeds ripen in 135-145 days. Depending on the weather conditions during the flowering period, 200-400 kg.ha-1 high seed yield may be obtained. Dry matter yield may reach $12-13 \mathrm{~kg} \cdot \mathrm{ha}^{-1}$.

\section{A7 \\ GENETIC DIFFERENCES MULTI-ANNUAL IMPACT OF LOPHODERMIUM SPP. NEEDLE CAST ON YOUNG SCOTS PINE}

\section{Āris Jansons, Una Neimane, Kaspars Polmanis, and Imants Baumanis}

Latvian State Forest Research Institute "Silava", LATVIA

aris.jansons@ silava.Iv

Needlecast may in future become a more frequent and severe problem in young Scots pine plantations due to changes in climate and forest regeneration practice. Fungi- 
cides are prohibited in forest stands; therefore, other solutions must be evaluated. The aim of the study was to assess the impact of Lophodermium needle cast on the survival and growth of Scots pine.

Repeated inventories of open-pollinated progeny trials (65 families, two sites) were carried out: height, height increment was measured, survival and damages by needle cast (in 5 grade scale, visually evaluating needles on annual shoot) were assessed at the age of three, four, and five years and the height of trees measured at the age of 12 years. Needlecast damages has a significant $(p<0.05)$ effect on annual height increment in the next season and survival as well as on the tree height at the age of 12 years, even if initial differences in tree height were used as covariate in the model. Degree of needlecast damage at the age of three years was a significant prediction for the degree of damages at the age of four and five years, suggesting a cumulative effect of the disease.

The degree of resistance has a genetic component $\left(\mathrm{h}^{2}=\right.$ $0.13-0.24$ ), that was relatively stable over three vegetation periods (family mean correlation $r_{\text {fam }}=0.77$ ). A cumulative effect of needle cast had been observed also at family mean level: correlation between the proportion of most affected trees (more than $65 \%$ of needles damaged) in family and family mean height at the beginning of the vegetation period as well as height increment in the first season of assessment was $r_{\text {fam }}=0.49$, in the second $-r_{\text {fam }}=0.89$. Both genetics (family) and level of damages by needle cast had a significant effect on tree height 7-9 years after the impact of the disease. Genotype $\mathrm{x}$ environment interaction influenced the resistance to the same extent as height growth: family mean correlation between two sites for tree height and for proportion of most affected trees was $r_{\text {fam }}=0.43$. Families belonging to particular populations had significantly $(p<0.05)$ less needlecast damages then families belonging to another. The degree of needlecast damage had no significant effect on the survival and height increment of trees from more resistant populations, suggesting that population differences are not only related to susceptibility to the disease, but also to the recovery rate after the damages.

The study was funded by the Latvian Council of Science project "Adaptive capacity of forest trees and possibilities to improve it" (No. 454/2012) and "Forest tree breeding for establishment of high genetic quality stands".
A8

\section{APPLICATION OF GENETIC MARKERS FOR STUDY OF NATURAL AND RESTTOCKING POPU- LATIONS OF SEA TROUT (SALMO TRUTTA L.) IN LATVIA}

\section{Artūrs Kārklinš and Natalja Škute}

Department of Ecology, Daugavpils University, LATVIA

carlie@ inbox.lv, natalja.skute@du.lv

Human impact on natural resources modifies them, changes the environment and biological resources. The use of small dams was restrictive to the fish migration. Sustainability of the sea trout population is ensured by artificial reproduction in this region. Artificial reproduction affects the natural fish population with genetic variation and artificially changes morphometric parameters. The sea trout (Salmo trutta L.), along with other representatives of the Salmonidae fish, is among the most valuable biological resources in Latvia. Microsatellite loci are useful markers to study the genetic structuring within species. Therefore, microsatellites could be of great help in an accurate characterisation of the natural and artificial populations of the sea trout. DNS was extracted from fish muscle by salt extraction method. The population genetic structure was analysed by eight microsatellite loci (Strutta 58, Strutta 12, Str 60, Str 73, Str 15, Str 543, Str 79 and Str 85) and statistically analysed by GenAlex programme. Genetic parameters, such as the percentage of polymorphic loci, the level of polymorphism, the level of heterozygosity, the number of private alleles per locus, genetic differences of wild sea trout population and smolts in aquaculture were calculated, compared, and analysed. The artificially reproduced fish specimens are more genetically different than the natural population. Heterozygosity decreases upstream the Salaca River, but the number of alleles increases, the greater the level of heterozygosity, the higher the number of average alleles and the number of private alleles. In the natural population, the higher upstream the river the fish live, the genetically more distant to each other they are. Artificially reproduced population, however, is genetically more distant within itself, than the naturally reproduced population. In the representative group, which is closest to the river estuary (the sea) there are much smaller genetic differences between individuals, as observed in the groups upstream the river $32 \%$ of molecular differentiation has been observed between natural and artificial reproduced populations. Information on the different genetic structure of the wild population and artificially reproduced population of the sea trout may be useful for sustainable development and preservation of the genetic diversity of fish populations, which are artificially reproduced, and decrease some negative effects caused by domestication. 
A9

\section{CHARACTERISATION OF PLOIDY LEVEL IN LIGULARIA SIBIRICA USING FLOW CYTOMETRY}

Nikole Krasṇevska, Dace Grauda, Oksana Fokina, and Isaak Rashal

Institute of Biology, University of Latvia, LATVIA

nikole.krasnevska@lu.Iv

Perennial herbaceous plant species Siberian Ligularia (Ligularia sibirica) are endangered and protected plant species in Latvia, which are included in the protected plants list of EU Habitat Directive 92/43/EEK Annexes 2 and 4. L. sibirica is one of only two species of genus Ligularia in Europe. The goal of the study was to collect samples of $L$. sibirica and compare ploidy level in existing populations, including such data as different ploidy cell lines. About 100 samples were collected from both only known species locations in Latvia. Determination of the ploidy level of $L$. sibirica was performed by BD FACSJazz ${ }^{\circledR}$ cell sorter (BD Biosciences, USA) with the flow cytometer function. Samples were prepared with Sysmex Partec kit 05-5022, 488 nm (blue) laser was used to initiate cell nucleus fluorescence. Ploidy was detected only for young leaves. $80 \%$ of samples were mixoploids (at least two different ploidy cell lines). The higher observed relative fluorescence was 40X in Zušu-Stain,u population.

Investigation was supported by the State Research Programme EVIDEnT.

\section{A10}

INHERITANCE AND DIVERSITY OF APPLE AND PEAR RESISTANCE TO SCAB CAUSED BY VENTURIA INAEQUALIS AND VENTURIA PYRINA

Gunārs Lācis, Irita Kota-Dombrovska, Toms Bartulsons, Baiba Lāce, and Laila Ikase

Institute of Horticulture, Latvia University of Agriculture, LATVIA

gunars.lacis@llu.Iv

Apples and pears are widely grown fruit species worldwide, but their production is reduced by pathogenic organisms and diseases, decreasing viability of plants, fruit development, and quality. Scab diseases on apple and pear caused by fungi Venturia inaequalis and Venturia pyrina are economically important globally. Currently scab control heavily relies on frequent fungicide applications and use of cultivars with resistance ensured by major genes. This strategy has led to changes and adaptations of the pathogen populations. Since the beginning of resistance breeding programmes based on major genes, several new races of $V$. inaequalis have developed the ability to overcome it, and pathogen populations with fungicide resistance have be- come common in many growing regions. It requires changes in apple and pear breeding strategies. Therefore, the aim of the study was to obtain new knowledge on the resistance inheritance, finding and characterization of possible resistance sources in Latvian Malus and Pyrus germplasm.

The study was designed as a complex of interrelated research activities:

- Screening of Malus and Pyrus germplasm field resistance (315 apple and 241 pear genotypes) for three years according to internationally recognized VINQUEST ${ }^{1}$ methodology in a fungicide non-treated genetic resources collection, which allowed to clarify cultivar resistance degree for further inheritance studies, identify new sources for resistance breeding.

- Screening of apple germplasm (161 genotypes) for known major resistance genes (Rvi2, Rvi4, Rvi5, Rvi6, Rvil1, Rvi12, Rvi13, Rvi15) using specific molecular markers. The highest occurrence had genes Rvi12, Rvi13, and Rvil4, whereas genes widely used in breeding ( $R v i 5$, Rvi6) were found only in the reference cultivars with known resistance and institute breeding material.

- Characterisation of apple and pear germplasm genetic diversity based on field evaluation results, using QRL (quantitative resistance loci) and NBS-LRR proteins coding gene markers. Thirty-two apple genotypes with different field resistance and under natural inoculation conditions were analysed for diversity of NBS-LRR class protein RPM1 coding gene $M d-N B S$, which has demonstrated resistance activity to fungal diseases in apple in connection with regulatory impact of miRNAs, providing adaptive properties of genome. For pears 195 genotypes have been tested for LG2 QTL markers to identify association with field resistance results.

Research was funded by the Latvian Council of Science, project No. 223/2012 "Studies on inheritance and diversity of apple and pear resistance to scab and characterization of races and population diversity of causal organisms - Venturia inequalis and Venturia pyrina".

\footnotetext{
${ }^{1}$ http://www.vinquest.ch/monitoring/collection.htm
} 


\section{COMPARISON OF SPRING BARLEY (HORDEUM VULGARE L.) POPULATION GENETIC DIVERSITY AND PERFORMANCE UNDER ORGANIC AND CONVENTIONAL FARMING SYSTEMS}

\author{
Linda Legzdina ${ }^{1}$, Dainis Runǵis ${ }^{2}$, leva Mežaka', \\ Indra Ločmele ${ }^{1}$, Dace Piliksere ${ }^{1}$, and Nelda Venta ${ }^{1}$ \\ ${ }^{1}$ Priekuḷi Research Center, Institute of Agricultural Resources and \\ Economics, LATVIA \\ 2 Genetic Resource Centre, Latvian State Forestry Research Insti- \\ tute "Silava", LATVIA \\ linda.legzdina@arei.Iv
}

Increasing genetic diversity in crops can ensure stability, adaptability, reduce disease severity, and improve competitive ability with weeds and nutrient uptake efficiency. Solution for increasing diversity within a variety of self-pollinating species is growing of populations which include higher levels of diversity if compared to pure lines and mixtures and are able to develop itself in time by adapting to the respective environment and providing buffering capacity. After hybridisation, population can be multiplied in the environment of interest with natural selection applied resulting in increase of frequency of better adapted plants. Our research aims at comparison of three population types: biparental populations (two parental genotypes), complex populations (more than two parents combined in one cross), and composite cross populations (CCPs, bulked diallel crosses among group of 10 parents). This presentation will include the preliminary results on examination of genetic diversity by nine SSR markers and testing under organically and conventionally managed field trials of four bi-parental populations, six complex populations, and three CCPs. The study on genetic diversity found that in bi-parental populations the average number of alleles ranged from 2.5 to 4.9 , in one complex population on average 3.4 alleles per loci were detected, whereas in CCPs it was from 5.3 to 5.9. Thus, CCPs showed larger intra-population variation than other types of studied populations. Two season results show that a significantly higher average grain yield was obtained for one CCP and one complex population surpassing the average of a group of five control varieties (3.74 t/ha) by 24 and $14 \%$, respectively. To compare the average yield of the three population types, there was a tendency for higher yield for CCPs and lower yield for bi-parental populations (3.92 t/ha versus $3.68 \mathrm{t} / \mathrm{ha}$ ), however, under organic location in one of the two seasons complex populations provided the best result.

\section{GENETIC STRUCTURE OF POPULATIONS OF ZE- BRA MUSSEL DREISSENA POLYMORPHA (PALLAS, 1771)}

\author{
Aleksandra Morozova and Natalja Škute \\ Department of Ecology, Daugavpils University, LATVIA \\ aleksandra.dimitrijeva@du.Iv, natalja.skute@du.Iv
}

Zebra mussels are alien invaders that have rapidly become established in European waterbodies. Dreissena polymorpha has been first recorded in Latvia since 1942. These mussels have colonised vast reaches of interconnected waterways in Europe and are continuing to expand their range. The invasion of the zebra mussel Dreissena polymorpha into European water bodies has resulted in profound ecological disturbances. Studies of population genetic structure will allow identification of the current situation of invasive species Dreissena polymorpha in Latvia. This study examined the genetic diversity among different populations of the zebra mussels using DNA microsatellite analysis. Mussels were collected for the study in July 2010-2016 from three lakes of Latvia, namely Svente, Riču, and Drīdzis. Samples were collected manually at a depth ranging to $1 \mathrm{~m}$, placed in $95 \%$ ethanol after collection and stored in a freezer $\left(-80{ }^{\circ} \mathrm{C}\right)$. The level of genetic diversity was estimated using GENALEX software version 6.41 with the following statistics: number of alleles $(\mathrm{Na})$, effective number of alleles (Ne), observed heterozygosity (Ho), expected heterozygosity $(\mathrm{He})$, and F-statistics calculations. Five polymorphic microsatellite loci for dreissenid mussels were developed and tested (DpolA6, Dpo101, Dpo221, Dpo260, Dpo272). Allelic diversity was high at all described loci, ranging from 10 to 15 alleles per locus. Some deviations from the expected heterozygosity level are considered normal for a stable natural population. Such deviation from the expected level of heterozygosity in all investigated populations was noticed. Mean observed heterozygosity $\left(\mathrm{H}_{\mathrm{o}}\right)$ per locus was 0.53 and mean expected heterozygosity $(\mathrm{He})$ was 0.88 per locus. Differentiations between observed and expected heterozygosity could be assortative mating result. Differentiation of the populations evidenced by pairwise Fst value. The highest Fst value was between Drīdzis and Svente populations, but the lowest Fst value was between Riču and Svente populations. Allelic variation was high in all investigated populations. Frequencies of alleles per locus varied. Fixation of 1 or 2 alleles were detected in all loci in all populations. PC1 and PC2 explain $74.9 \%$ and $25.02 \%$ of the total variation, respectively. The Latvian population of zebra mussel, compared with other European populations of zebra mussel (Poland, Nederland, Spain, and Hungary) has a high genetic variability, close to the native populations of zebra mussel in Ukraine and Russia.

The research project was supported by the National Research Programme 2014-2017 "EVIDEnT" Sub-project 2.4. "Non-indigenous species distribution and impact on freshwater ecosystems". 


\section{GENETIC MONITORING DATA OF VENDACE COREGONUS ALBULA (L.) POPULATIONS IN THREE LATVIAN LAKES}

\section{Jeḷena Oreha and Nataḷja Škute}

Institute of Life Sciences and Technology, Daugavpils University, LATVIA

jelena.oreha@du.lv, natalja.skute@du.lv

At the beginning of the last century, the vendace Coregonus albula (L.) was introduced from lakes Ladoga (Russia) and Peipus (Estonia) to more than 30 Latvian lakes. Presently vendace is found in several Latvian lakes and is included in the list of protected species with restricted use in Latvia. Therefore, the study of genetic structure of vendace populations is needed to determine processes which affect the genetic structure of these populations. The objective is to investigate temporal changes in population genetic structure and genetic diversity of Coregonus albula populations in three Latvian lakes. Vendace samples were collected from three Latvian lakes, namely Lake Sventes, Lake Drīdzis, and Lake Stirnu in 2007 and 2012. Microsatellite assays were assessed using six microsatellite markers (BWF1, Cisco90, Cisco126, Cisco157, Cisco200, Cisco106). The existence of null alleles, the bottleneck effect, number of alleles, observed and expected heterozygosity, departures from Hardy-Weinberg equilibrium and linkage disequilibrium were determined for each locus and population. Genetic differentiation of the three vendace populations were estimated by the $\mathrm{F}_{\mathrm{ST}}$. Allelic variation was quite high in all investigated vendace populations in samples of the year 2007, as well as in those of the year 2012. However, differences were detected in the number of private alleles in Lake Stirnu vendace population. Frequencies of alleles varied slightly in all investigated loci in samples of the years 2007 and 2012. Differences were detected also in allelic variation in Cisco126, Ciscol57 loci. There were "null" alleles detected in Ciscol06 locus. The recent bottleneck was detected in Stirnu population of vendace sampled in 2007; however, this one was not detected in Stirnu population of vendace sampled in 2012. Observed heterozygosity was quite high in the vendace samples of the year 2007 (0.58-0.73), and in those of the year $2012(0.61-0.75)$. The observed heterozygosity deviated significantly from the expected value only in the samples of the year 2012. There were significant deviations from Hardy-Weinberg equilibrium in Ciscol57 locus in all three populations (heterozygote excess) and in Cisco90 locus in Lake Drīdzis (homozygote excess) population. Allele frequencies become more uniformly distributed in Lake Stirnu vendace population in the year 2012, compared to the year 2007 (i.e. bottleneck effect was not detected anymore). However, some alleles were not detected in Stirnu sample of the year 2012, which had been detected in the sample of the year 2007. Despite the new detected alleles and some "lost" alleles in samples of the year 2012 the revealed fluctuations of allele frequencies may be the result of gene drift. It was revealed that the vendace population in Lake Stirnu is more variable. These populations may be differentiated due to drift, reduced gene flow and possibly natural selection that is promoting divergence.

This study has been supported by the Latvian-Belarusian Science Foundation project No. 11-3/IZM14-14 "The ecological and genetic aspects of protection of salmonid fish sympatric populations in Latvian-Belarusian Lakeland".

\section{A14 \\ POLYMORPHISM OF KAPPA-CASEIN (CSN3) GE- NOTYPES IN LATVIA NATIVE COWS}

\section{Solvita Petrovska, Lāsma Cielava, Daina Jonkus, and Dace Smiltina}

Latvia University of Agriculture, Jelgava, LATVIA

solvita.petrovska@inbox.Iv

Kappa-casein gene (CSN3) has very important influence on the milk quality and milk coagulation properties. The CSN3 gene is situated on cattle chromosome 6 and polymorphism of CSN3 has been known since 1964. Alleles A, B, and E are most often investigated. Allele A increases milk yield and decreases protein content, also allele $\mathrm{B}$ increases protein quality and coagulation properties, but $\mathrm{E}$ allele effects milk coagulation properties negative. The aim of the research was to identify polymorphism of CSN3 genotypes in Latvia native dairy cows. CSN3 genotypes were identified in 120 Latvian brown (LB) and 101 Latvian blue (LZ) cows using Polymerase Chain Reaction and Restriction Fragment Length Polymorphism (PCR-RFLP) and electrophoresis on $3 \%$ agarose gel. Identification of CSN3 single nucleotide polymorphisms (SNPs) was done according to Velmala et al. (1993). SNPs at positions 13104 and 13124 were examined to determine the nucleotide changes $(A->C$ and $A->G)$, which determine CSN3 alleles A, B, and also E. For digestions endonuclease Hinfl was used to detect the presence of alleles A and B, and endonuclease BsuRI, to detect the presence of the allele E. The research of CSN3 polymorphisms started from 2015. Identification of CSN3 genotypes was done in the Scientific Laboratory of Molecular Biology and Microbiology of Latvia University of Agriculture. LB and LZ cows are animal genetic resources (AnGR) in Latvia. The number of these animals decrease each year, because milk yield is lower than, for example, of Holstein cows. It is important to find perspective application of these native breeds. Identification of milk protein genes' polymorphisms can help to select animals, which are producing milk for cheese preparation. Frequency of CSN3 genotype AA in LB was 0.5667 , but frequency in $\mathrm{LZ}$ was 0.2376 . We found that the highest frequency of genotype BB was in LZ comparing with LB -0.1980 and 0.0417 , respectively. Genotype AE was identified in LB with frequency 0.0250 , but genotype $\mathrm{BE}$ was in LZ with frequency 0.0090 . Frequency of allele A 
was 0.7625 in LB, but in LZ it was 0.5149. The highest frequency of allele B was observed in LZ, respectively 0.4802 , while in LB breed it was 0.2250 . Highest frequency of allele $\mathrm{E}$ was observed in LB.

The research is supported by VPP AgroBioRes 3 project.

\section{REFERENCES}

Velmala, R., Mantysaari, E. A., Maki-Tanila, A. (1998). Molecular genetic polymorphism at the k-casein and b-lactoglobulin loci in Finnish dairy bulls. J. Agr. Sci. Finland, 26, 431-435.

\section{A15}

\section{CULTIVARS OF GARDEN PEA COMPARISON}

\section{Aivars Pogulis}

"Pilsumi" Farm, Aloja Municipality, LATVIA

aivars.pogulis@inbox.Iv

Peas is one of the oldest food crop and are commonly grown in home gardens. Garden pea cultivars nowadays are widely cultivated, but information about cultivation in Latvia is lacking. The characteristics of garden pea cultivars on seed packages often is brief and incomplete. A field experiment took place from 2013 to 2015 in the farm "Pilsumi" $\left(57^{\circ} 45^{\prime} 8.45^{\prime \prime} \mathrm{N}, 24^{\circ} 55^{\prime} 49.6^{\prime \prime E}\right)$ of Aloja Municipality, Latvia. The field trial included comparison between 18 cultivars of garden pea (Pisum sativum L.): 'Alderman', 'Alfa', 'Blauwcshokker', 'Bördi', 'Cud Kelvedonu', 'Dark Skin Perfection', 'Early Onward', 'Gloriosa', 'Kelvedon Wonder', 'Linkoln', 'Meteor', 'Nefryt', 'Onward', 'Pegaz', 'Rondo', 'Progress 9', 'Senator', and 'Telefon'. The field experiment was performed on sod-podzolic loamy soil. Soil agro-chemical parameters in 2013 and 2014 were the following: humus content $18 \mathrm{~g} \cdot \mathrm{kg}^{-1}, \mathrm{pH} \mathrm{KCl} \mathrm{5.7,} \mathrm{plant} \mathrm{usable}$ $\mathrm{P}_{2} \mathrm{O}_{5}$ content (by Egner-Rheem method) 39 and plant usable $\mathrm{K}_{2} \mathrm{O}$ (by Egner-Rheem method) - $133 \mathrm{mg} \cdot \mathrm{kg}^{-1}$; and in 2015 these were: humus content $37 \mathrm{~g} \cdot \mathrm{kg}^{-1}, \mathrm{pH} \mathrm{KCl} \mathrm{6.3,}$ plant usable $\mathrm{P}_{2} \mathrm{O}_{5}$ content 399 and plant usable $\mathrm{K}_{2} \mathrm{O}-129$ $\mathrm{mg} \cdot \mathrm{kg}^{-1}$. Garden peas were sown by hand in the first decade of May, in one row, with $50 \mathrm{~cm}$ wide beds. The seed density was $3-5 \mathrm{~cm}$ apart and $4-5 \mathrm{~cm}$ deep. Peas were grown without application of fertilisers. Plants were supported with 1.5 to 2.0 meter tall wood fencing props. After sowing of peas, weeds were regularly manually controlled. Peas with pods harvested manually in the stage of full ripeness and dry seed (moisture standard 14\%) yield were calculated. The results of seed yield and yield components showed that the yield was greatly influenced by environmental factors such as soil agrochemical properties (soil acidity, plant nutrients content), temperature, and precipitation. The average results of dry seed yields of garden pea cultivars from 2013 to 2015 ranged from $2.37 \mathrm{t} \cdot \mathrm{ha}^{-1}$ ('Bördi') to $8.50 \mathrm{t} \cdot \mathrm{ha}^{-1}$ ('Telefon'). Dry seed yield under $4.00 \mathrm{t} \cdot \mathrm{ha}^{-1}$ in three years on average was in 'Bördi', 'Dark
Skin Perfection', 'Alderman', 'Onward', 'Blauwcshokker' and 'Meteor'. The average results from 2013 to 2015 of 1000-seed mass of garden pea cultivars ranged from 191.61 g ('Early Onward') to 324.43 g ('Telefon'). Plant height under $70 \mathrm{~cm}$ was in 'Meteor' and 'Progress 9'; from 71 to 100 cm it was in 'Cud Kelvedonu', 'Early Onward', 'Kelvedon Wonder', 'Bördi', 'Nefryt', 'Pegaz', 'Alfa', and 'Dark Skin Perfection"; over $100 \mathrm{~cm}$ it was in 'Rondo', 'Gloriosa', 'Linkoln', 'Senator', 'Telefon', 'Alderman', 'Blauwcshokker', and 'Onward'.

\section{A16}

\section{ENHANCING OF ACQUISITION OF TETRAPLOID RED CLOVER (TRIFOLIUM PRATENSE L.)}

\author{
Aija Rebāne ${ }^{1}$, Biruta Jansone ${ }^{1}$, Sarmīte Rancāne ${ }^{1}$, \\ Aldis Jansons ${ }^{1}$, and Dace Grauda ${ }^{2}$ \\ ${ }^{1}$ Research Institute of Agriculture, Latvia University of Agriculture, \\ LATVIA \\ 2 Institute of Biology, University of Latvia, LATVIA \\ aijarebane@inbox.Iv
}

The papilionaceous plants have a high value of biomass, they are an excellent source of proteins and have an indispensable role in improving the soil with nitrogen, which is particularly crucial for ecological agriculture. Expanding of the sowing area of these plants currently is a priority task of agriculture in many European countries including Latvia. Trifolium family is very wide comprising more than 300 species, but mainly the red clover (Trifolium pratense L.) is grown in Latvia. Diploid (2n) red clover with 14 chromosomes is most widely used in creating sward in meadows and pastures. In recent years, attention is more paid to tertraploid species $(4 n=28)$, which are characterised by a higher yield and disease resistance. The aim of red clover breeding programme is development of varieties with high adaptation potentially unable to create a stable yield of biomass and seeds, winter-hardy, long-term and durable against diseases and pests. Since the 1960s, the main red clover breeding method in LUA (Latvia University of Agriculture) Institute of Agriculture is free intervarietal hybridisation and the following individual and mass selection. For acquisition of tetraploid breeding source material the most common method is the chromosome number doubling using colchicine. As a result of cooperation between LUA Institute of Agriculture and University of Latvia Institute of Biology Environmental Genetics Laboratory methods for enhancing of acquisition of tetraploid red clover breeding source material were elaborated. In vitro methods for chromosome doubling of plantlets and in vitro cultivation of the tetraploid plantlets were developed. For ploidy determination the BD FACSJazz cell sorter with the flow cytometer function was used. A high proportion of cells with different ploidy plantlets after incubation in colchicine was found. 
An influence of genotype was observed on tetraploid cell development and plantlets surviving after colchicine treatment. Plantlets with well-developed roots in 2-3 leaves stage were planted in soil and grown in a greenhouse for about a month, then replanted in the soil in field conditions and grown till maturity. After evaluation, 30 plants were chosen for the further breeding programme. In the next progeny (generation) of red clover $60 \%$ of stable tetraploid plants were established. The plants were planted in five isolated places in LUA Institute of Agriculture grass breeding crop rotation fields. The distance between the plants was 30 $\mathrm{cm}$ and $70 \mathrm{~cm}$ between the rows. The clover was evaluated by red clover's descriptors (IBPGR descriptors (1985)).

The research was supported by the Latvian Ministry of Agriculture within the Crop Breeding Program sub-program "Investigation of breeding material of perennial grasses to implement integrated technologies in crops".

A17

\section{LATVIAN PLANT GENETIC RESOURCES: CON- SERVATION AND USE}

\author{
Dainis Ruṇǵis, Agnese Gailīte, and Anita Gaile \\ Genetic Resource Centre, Latvian State Forest Research Institute \\ "Silava", LATVIA \\ dainis.rungis@silava.Iv
}

Biodiversity is an integral component of sustainable ecosystems, and given the rapid increase of the global human population, as well as the effects of climate change, a sustainable increase of agricultural production is of high priority to ensure food security. Genetic resources can provide novel traits and compounds for use in breeding, medicine, and other areas. Plant genetic resources for food and agriculture (PGRFA) are plant material (species, varieties, populations) that can be utilised in agriculture and/or breeding. The number of varieties available in the market has reduced by $75 \%$ since the beginning of the $20^{\text {th }}$ century, therefore, it is critical that landraces and old varieties, as well as crop wild relatives (CWR) are conserved as much as possible, as these can provide an important source of genetic diversity. They are also an important cultural and historical heritage. Genetic resources can be conserved both in ex situ (in gene banks), as well as in situ (on-farm and CWR). The Latvian Gene Bank was established in the 1990s, and Latvian genetic resources are conserved in the gene bank, field collections, and in vitro. Characterisation and evaluation, and genetic fingerprinting activities have been initiated to facilitate the further use of the conserved genetic resources. Both ex situ and in situ conservation approaches should be utilised to maximise the diversity and adaptive potential of PGRFA. Currently, over 2200, seed accessions are conserved in the Latvian gene bank, with an additional 500 accessions in field and in vitro collections.
The development of a Latvian in situ conservation strategy encompassing both "on-farm" conservation as well as CWR is required. In order to accomplish this, a priority list of CWR species will be compiled, and expeditions conducted to identify landraces/old varieties and to survey CWR sites.

\section{A18 \\ MOLECULAR GENETIC STUDIES IN LATVIAN FORESTRY}

Dainis Runǵis, Vilnis Škipars, Angelika Voronova, Baiba Krivmane, Ilze Šṇepste, Viktorija Beḷeviča, Anna Korica, Krista Kānberga-Siliṇa, Krišs Bitenieks, Elza Rauda, and Ilze Veinberga

Genetic Resource Centre, Latvian State Forest Research Institute "Silava", LATVIA

dainis.rungis@silava.Iv

Forest tree species are long-lived, diverse, and adaptable organisms that often form large populations, both spatially and numerically. The Genetic Resource Centre at the Latvian State Forest Research Institute "Silava" has initiated a range of research directions, investigating the population structure, provenance, and adaptation of Latvian forest tree species populations. A close collaboration with the tree breeding programme has been established, and research objects include breeding germplasm, seed plantations, species hybrids, and forest genetic resource stands. In addition, research has been done on the structure and activation of retrotransposon-like sequences (Voronova and Rungisis, 2013; Voronova et al., 2014), gene expression in pine trees with differing wood properties (Kānberga-Siliņa et al., 2015), induced resistance in Scots pine and micro RNAs in Scots pine. Population genetic studies of a range of conifer and broadleaf species have been done using nuclear SSR markers, chloroplast and mitochondrial markers. In many cases, the analysed markers have been utilised in previous studies allowing comparison with published results from other European regions. These population analyses enable determination of genetic diversity and differentiation, as well as identification of possible introduced germplasm (Ruņgís et al., 2016). In addition, the degree and direction of natural hybridisation between species can be determined (Runğis et al., submitted). The result of these population studies can be utilised to assess the suitability of existing forest genetic resource stands, as well as identifying possible introduced material, which may have differing adaptive properties or other traits. Studies on the molecular mechanisms of Scots pine resistance to pathogen infection include determination of changes in gene expression, analysis of resistance gene copy number (Škipars et al., 2011), and correlation with expression levels, as well as investigation of micro RNAs after methyl jasmonate treatment. 


\section{REFERENCES}

Kanberga-Silina, K., Jansons, A., Rungis, D. (2015). Expression of three phenylpropanoid pathway genes in Scots pine (Pinus sylvestris L.) in open-pollinated families with differing relative wood densities during early and late wood formation. Silvae Genetica, 64 (4), 148-159.

Ruņgis, D, Korica, A., Pušpure, I., Veinberga, I. (2016). Analysis of the genetic diversity and population structure of Latvian ash (Fraxinus excelsior L.) stands using nuclear and chloroplast SSR markers. Proc. Latvian Acad. Sci., Section B, 70 (3), 101-108.

Škipars, V., Krivmane, B., Ruṇgis, D. (2011). Thaumatin-like protein gene copy number variation in Scots pine (Pinus sylvestris). Environ. Exper. Biol., 9, 75-81.

Voronova, A., Belevich, V., Jansons, A., Rungis, D. (2014). Stress-induced transcriptional activation of retrotransposon-like sequences in the Scots pine (Pinus sylvestris L.) genome. Tree Genet. Genomes, 10 (4), 937-951.

Voronova, A., Rungǵis, D. (2013). Development and characterisation of IRAP markers from expressed retrotransposon-like sequences in Pinus sylvestris L. Proc. Latvian Acad. Sci., Section B, 67 (6), 485-492.

Ruņğis D., Laiviņš M., Gailīte A., Korica A., Lazdiņa D., Šķipars V., Veinberga I. Genetic analysis of Latvian Salix alba L. and hybrid populations using nuclear and chloroplast DNA markers. iForest (accepted for publication).

\section{A19}

\section{GENETIC DISCRIMINATION OF CLOSELY RE- LATED ISOLATES OF PHOMA SP. USING RETROTRANSPOSON-BASED PCR ASSAYS}

\author{
Vilnis Šķipars', Maryna Siaredzich², Viktorija \\ Beleviča1', Lauma Brūna', and Dainis Ruṇǵis ${ }^{1}$ \\ ${ }^{1}$ Latvian State Forest Research Institute "Silava", LATVIA \\ 2 Belarusian State Technological University, BELARUS \\ vilnis.skipars@silava.Iv
}

Phoma blight is an infectious disease, which attacks agricultural and forest plant species and is caused by Phoma spp. fungi. Phoma fungi can attack various tissues of fir, spruce, pine, larch, Douglas fir, maple, ash, walnut, birch, and some other tree species. Phoma blight is most harmful to young plants, including seedlings and saplings, which are cultivated in forest nurseries. Phoma species are notoriously difficult to identify due to the plasticity of morphological features when cultivated on agar media. To elucidate the Phoma genus, which is one of the largest and most complicated genera, scientists have turned to sequence analysis. This is time-consuming and expensive for large numbers of samples both for pathogen screening in nurseries and for population genetics studies. Instead of sequencing, we utilised retrotransposon-based primers in a PCR assay. The PCR products were analysed by agarose gel electrophoresis. This procedure is cost-effective, less time-consuming and allows differentiation between isolates of the same species, thus also facilitating population genetic studies. We conclude that retrotransposon-based PCR assays differentiate between different species and isolates of the same species; of 11 primers tested, 8 show no significant non-specific amplification, not all tested primers are suited for discrimina- tion of isolates but all tested primers discriminate between species; species discrimination capabilities of the tested assays have to be determined using a larger number of species and several isolates of each of these species; Belarusian isolates show obvious differences from Latvian $P h$. glomerata and $P h$. herbarum isolates and are probably different Phoma species.

\section{A20 \\ APPLICATION OF LUMA FOR MEASUREMENT OF GLOBAL DNA METHYLATION IN DIFFERENT PLANTS}

\author{
Natalja Škute, Marina Savicka, Nadežda \\ Harlamova, and Juris Pikeli
}

Institute of Life Sciences and Technology, Daugavpils University, LATVIA

natalja.skute@du.Iv, marina.savicka@du.lv

Enzymatic methylation of nuclear DNA with creation of 5 -methylcytosine $(5 \mathrm{mC})$ is one of major mechanisms of epigenetic modification. The epigenetic states of plant genes are often stably inherited through generations and extensively methylated at two types of symmetric sequences, namely $\mathrm{CpG}$ and $\mathrm{CpNpG}$, as well as at asymmetric ones $\mathrm{CpNpN}$. DNA methylation in plants is involved in the control of all genetic functions and it is one of the possible modes of the hormonal action. To analyse the global genomic DNA methylation, a method using a luminometric technology to quantitate methylation sensitive restriction digestions was applied. The LUminometric Methylation Assay (LUMA) is permissive for genomic DNA methylation studies of any genome as it relies on the use of methyl-sensitive and -insensitive restriction enzymes followed by polymerase extension via pyrosequencing technology. LUMA is a convenient choice because it requires a relatively small DNA sample and has a short processing time. A potential limitation of LUMA is only measurement of $\mathrm{CpG}$ methylation within the recognition sequences of the restriction enzymes (CCGG), and thus it will not give information about methylation outside of this sequence. Our study showed that LUMA is sensitive to poor DNA quality and DNA fragmentation. Until recently, LUMA has been principally used for biomedical research and for animal ecological study. In this study for the first time the LUMA method was used for ecological investigations of different plants (Elodea canadensis, Liparis loeselii (L.)) and for fundamental investigation of plant senescences (Nicotiana tabacum). DNA was isolated from plant leaves using the DNeasy Plant kit (Qiagen). DNA was quantified spectrophotometrically and DNA fragmentation was checked by agarose gel-electrophoresis. HpaII, MspI, and EcoRI were used for digestion reaction. PyroMark Gold Reagents (Qiagen) were used for luminometric methylation assay. 
Percent methylation is calculated as:

1-[(HpaII(C)/EcoRI(A))/(MspI(C)/EcoRI(A)) ]*100. It was shown that the global DNA methylation level decreased in the senescent leaves of Nicotiana tabacum (to $40 \%$ ). DNA methylation in leaves of Liparis loeselii (L.) from different places in Latvia was the same, except Lake Engure, in which the environmental conditions are different from those in other places. DNA methylation in leaves of Liparis loeselii (L.) from this lake was higher (to 30\%) than in other places. Our data show that abiotic stresses such as salinity increase the level of global DNA methylation in Elodea canadensis leaves. There is a relationship between salt concentration and DNA methylation level in E. canadensis leaves $\left(\mathrm{R}^{2}=0.9\right)$. Therefore, the LUMA method can be used as a universal method for investigations of epigenetic changes in plants during different processes.

Part of the study has been supported by the National Research Programme 2014-2017 "EVIDEnT" sub-project 1.4. "Functioning of food-webs" and sub-project 4.6. "Freshwater ecosystem services and biological diversity".

\section{A21}

\section{COMPARATIVE SUMMARY OF LATVIAN BLUE AND LATVIAN BROWN COW BREEDS ON MILK PROTEIN GENES}

\section{Dace Smiltina, Ziedonis Grīslis, and Rita Sarma}

Institute of Agrobiotecnology, Faculty of Agriculture, Latvia University of Agriculture, Jelgava, LATVIA

dace.smiltina@llu.Iv

Latvian native breeds of dairy cattle (Bos taurus) are Latvian Blue (Latvijas zilā, LZ) and Latvian Brown (Latvijas Brūnā, LB) which have a status of Animal Genetic Resources (AnGR), which historically were interbreeded in the Latvian territory, but for improvement had been mixing with other breeds of dairy cow. The aim of the research was to explore and to collate milk protein polymorphisms of the AnGR populations of LZ and LB breeds in Latvia. For genotyping, polymorphisms by five most analysed genes of milk protein were chosen: for alfa $\mathrm{S} 1$ - casein or CSN1S1 c., $175 \mathrm{~A}>\mathrm{G}$, which lead to protein variation change $\mathrm{B}$ to $\mathrm{C}$; for beta - casein or CSN2, c. 4451A > C (Pro $67(82)_{\text {His; }}$ $\mathrm{A} 1$ and A2 variations); for kappa - casein of CSN3, two SNPs were selected: c. $11625 \mathrm{C}>\mathrm{T}$ and c. $11661 \mathrm{~A}>\mathrm{C}$, which lead to $\mathrm{Thr}_{136(157)}$ Ile and $\mathrm{Asp}_{148(169)}$ Ala or variation A change to $\mathrm{B}$. For whey proteins, respectively, for alfa, lactalbumin or $L A A$ was selected, SNP located in notranslated region or c. $15 \mathrm{~A}>\mathrm{G}$, in which case it is considered that changes A variation of the $\mathrm{B}$, but for beta - lactoglobulin or $L G B$ c. $3106 \mathrm{~T}>\mathrm{C}$, which lead to the amino acid change $\mathrm{Val}_{118(134)}$ Ala or protein variation change $\mathrm{A}$ to B. Analysed polymorphisms of milk protein genes were genotyped in 367 LB and 179 LZ cows using Polymerase
Chain Reaction and Restriction Fragment Length Polymorphism (PCR-RFLP), in 2009-2014. In both breeds the common allele and genotype of CSN1S1 gene was B and BB with frequencies about $95-96 \%$ and $90-93 \%$. Allele A1 of CSN2 gene in both breeds was common, there is statistically significant difference in frequencies: 69.32 vs. 76.40 for LB and LZ cows $\left(p=1.50 \times 10^{-2}\right)$. There are different common genotypes: for LB cows, it is heterozygote A1A2 with frequency 49.86 , but for LZ - homozygote of common allele $\left(55.62 ; \mathrm{p}=3.05 \times 10^{-2}\right)$. For both breeds the frequency of genotype A2A2 was very low (5.75 and 2.81). In case of CSN3 gene for $\mathrm{LZ}$ cows allele B were found four times more common than for LB cows (28.46 vs. 7.19; $\mathrm{p}=$ $2.09 \times 10^{-12}$ ). In LB breed the common genotype is AA of common allele A, and the frequency is $87.96 \%$, but in LZ breed the same genotype was $53.85 \%$. The third statistically significant gene/protein in the distribution of alleles and genotypes was $L A A$ gene of whey protein. In both breeds common allele and common genotype is similar - allele B and genotype BB. In LZ rare allele was found (2.91 vs. $7.75 ; \mathrm{p}=1.25 \times 10^{-3}$ ) and heterozygote genotype (5.82 vs. $\left.15.49 ; \mathrm{p}=9.48 \times 10^{-4}\right)$. In case of $L G B$ gene data about distributions of alleles and genotypes in LB and LZ breeds were similar: common allele was B (about 81.50\%) and common genotype was $\mathrm{BB}$ (about $64.13 \%$ ). The results were comparing with data of other national breeds of cow of Baltic States.

The study was supported by financing of the Research Project No. 09.1461 of the Latvian Science Council and the European Regional Development Fund project No. 2009/0180/1DP/1.1.2.1.2/09/IPIA/VIAA/017/.

\section{A22 \\ SUSCEPTIBILITY OF BARLEY CULTIVARS TO DIS- EASES IN LATVIA}

Olga Treikale, Skaidrīte Būmane, Zane Vigule, Līga Feodorova-Fedotova, Elīna Anna Brauna, and Jūlija Volkova

Latvian Plant Protection Research Centre, LATVIA

olga.treikale@laapc.lv

In this study, spring barley cultivars were investigated on susceptibility to foliar infection by Pyrenophora teres, Blumeria graminis f.sp. hordei, Stagonospora nodorum, Rhynchosporium secalis, Helminthosporium sativum, Puccinia hordei, to root rot infection by Bipolaris sorokiniana and Fusarium spp. and to ear infection by Ustilago nuda and Fusarium head blight (FHB) that occurred in the field under natural conditions in 2010-2015 without using of fungicides. The field trials were established in the southwest (Saldus) and central part (Jelgava) of Latvia. Different diseases occurred at the trial sites and the severity level depended on the meteorological conditions during the grow- 
ing season, especially on the air temperature in July. The net blotch was the most widely spread disease in all years of investigations. The tendency of the infection rate of the net blotch to regress, under the increase of the air temperature was observed. Logarithmic regression of Pyrenophora teres severity in spring barley cultivars, with the air temperature increase, was statistically significant for July mean data, by a negative correlation coefficient $(\mathrm{r}=-0.537, p<0.05)$. Under the conditions of natural infection, 18 of 49 tested cultivars were relatively resistant to the net blotch, which corresponds to the infection level of the local breeding cultivar 'Ansis' used as a standard in all years of investigations. Four of the relatively resistant cultivars were also local breeding lines, therefore, the domestic cultivar 'Idumeja' was more severely infected by the net blotch. According to data analysis, five cultivars were resistant to the powdery mildew, under a severe infection in 2010. Domestics cultivars were relatively resistant, but cultivar 'Gustav' was more infected. Cultivars 'KWS Hobbs', 'KWS Dunkan', and 'Justina' were more infected by the root rot caused by Fusarium spp. and Bipolaris sorokiniana. The domestic cultivars 'Ansis', 'Druvis', 'Kristaps', and 'Iron' were infected by Helminthosporium sativum. Leaf infection by Stagonospora nodorum in the trials was observed in 2013 and 2014. Under a slight attack of the disease, cultivars 'Propino' and 'Kornelija' showed susceptibility to Stagonospora nodorum. Rhynchosporium secalis on spring barley under the conditions of the trials was observed only in 2011, at a low level of infection. The cultivars 'Olavi', 'Streif', 'Kristaps', and 'Ansis' showed susceptibility to Rhynchosporium secalis. Occurrence of Puccinia hordei in the trials at a slight level of infection was observed in 2012, 2013, and 2014. Susceptibility to Puccinia hordei was shown by cultivars 'Kornelija', 'Quench', 'Sanette', 'Conquest', and 'Iron'. At the same time, the cultivars 'Passenger', 'Ansis', 'Evergeen', 'Shallo', and 'Milford' were clean from the rust infection. Fusarium head blight infection in spring barley was observed yearly, and mostly severe ear infection was evaluated in cultivars 'Prestige', 'Su Lilly', KWS 'Asta', and 'Evergeen'. The local cultivars 'Kristaps' and 'Ansis' showed a relative resistance to FHB. The results of research on the infection by harmful diseases of spring barley domestic cultivars, and the absence of some disease symptoms on foreign cultivars, suggest that it is necessary to pay attention on the breeding programme in Latvia for creating new cultivars with resistance to these pathogens.

The study was supported by the Latvian Ministry of Agriculture within the research project 24/2008-2014 "Evaluation of the cereal cultivars to diseases in Latvian agroclimatic conditions".
HYBRIDISATION BETWEEN THE EUROPEAN AND ASIAN FORMS OF HARTING' VOLE MICROTUS HARTINGI (RODENTIA, ARVICOLINAE) AND MICROTUS SOCIALIS

\author{
Tanya Zorenko and Isaak Rashal \\ Faculty of Biology, University of Latvia, LATVIA \\ tatjana.zorenko@lu.Iv, izaks.rasals@lu.Iv
}

The aim of the investigation was to identify particularities of hybridisation of Microtus hartingi subspecies lydius, $2 \mathrm{n}$ = 54) with the social vole $M$. socialis $(2 \mathrm{n}=62)$. Earlier it was shown that in case of hybridisation of $M$. $h$. subspecies strandzensis with individuals of four subspecies of $M$. socialis mating and the birth of hybrid offspring was observed in $43-73 \%$ of pairs, but both males and females of $F_{1}$ were sterile (Zorenko et al., 1997). The results of hybridisation of M. h. lydius with M. socialis subspecies socialis or nikolajevi depended on parental subspecies and the direction of crossing. Sometimes copulation and pregnancy were established which, in rare cases, resulted in offspring which all were sterile. Often there occurred interruption of the programme of the embryos' development of interspecific hybrids during early embryogenesis. The weight of the testes and its epididymis of hybrid males were three times smaller than in parental species. Reciprocal hybridisation of $M . h$. lydius and $M$.s. nikolajevi showed that the individuals of $\mathrm{F}_{1}$ generation usually possess morphological characteristics of the maternal species (body weight, tail and foot length, etc.). Post-zygotic reproductive isolation was observed among all investigated subspecies of $M$. hartingi and $M$. socialis. Pre-zygotic isolation that prevents mating by a decreased level of males' motivation at the meeting with heterospecific females and by suppression of female sexual cycles was observed only among subspecies $M$. $h$. lydius and M. s. socialis. Particular attention was paid to the behaviour of hybrids in the open-field test. It was observed that the behaviour of $\mathrm{F}_{1}$ generation of cross $M$. h. lydius with $M$. s. nikolajevi significantly differed from the behaviour of the parental species. Locomotor activity of hybrids increased significantly but immobility and cleaning frequency decreased. The results of hybridisation of social voles will be also analysed from the point of view of possible heterosis effect.

\section{REFERENCES}

Zorenko, T. A., Golenishchev, F. N., Skinderskaya, I. A. (1997). Peculiarities of the behaviour in social voles of the subgenus Sumeriomys (Arvicolinae, Microtus) in hybridization. Baltic J. Labor. Animal Sci., 7 (2), 77-102 (in Russian). 


\section{INDEX OF AUTHORS OF ABSTRACTS}

Baders, Endijs A4

Bartulsons, Toms A10

Bārzdina, Dace A1

Baumanis, Imants A4, A7

Bel̦eviča, Viktorija A18, A19

Belogrudova, Inta A5

Bitenieks, Krišs A18

Bleidere, Māra A2

Brauna, Elīna Anna A22

Brūna, Lauma A19

Būmane, Skaidrīte A22

Bumbure, Lada A5

Cielava, Lāsma A14

Fedorova-Fedotova, Līga A22

Fokina, Oksana A3

Gaile, Anita A17

Gailis, Arnis A4

Gailite, Agnese A17

Grauda, Dace A3, A5, A9, A16

Grīslis, Ziedonis A21

Grunte, Ilze A2

Harlamova, Nadežda A20

Ikase, Laila A10

Jansone, Biruta A6, A16
Jansons, Aldis A6, A16

Jansons, Āris A4, A7

Jermuša, Galina A6

Jonkus, Daina A14

Kairiša, Daina A1

Kānberga-Siliņa, Krista A18

Kārkliṇš, Artūrs A8

Kolodinski, Anton A5

Korica, Anna A18

Kota-Dombrovska, Irita A10

Krasņevska, Nikole A9

Krivmane, Baiba A18

Lāce, Baiba A10

Lācis, Gunārs A10

Legzdina, Linda A11

Ločmele, Indra A11

Loskutov, Igor A2

Mežaka, Ieva A11

Morozova, Aleksandra A12

Neimane, Una A7

Oreha, Jeḷena A13

Petrovska, Solvita A14

Piķelis, Juris A20
Piliksere, Dace A11

Pogulis, Aivars A15

Polmanis, Kaspars A7

Puriņš, Mārtiņš A4

Rancāne, Sarmīte A6, A16

Rashal, Isaak A3, A5, A9, A23

Rauda, Elza A18

Rebāne, Aija A6, A16

Ruṇgis, Dainis A11, A17, A18, A19

Sarma, Rita A21

Savicka, Marina A20

Siaredzich, Maryna A19

Škipars, Vilnis A18, A19

Škute, Nataljja A8, A12, A13, A20

Smiltina, Dace A14, A21

Šnepste, Ilze A18

Treikale, Olga A22

Veinberga, Ilze A18

Venta, Nelda A11

Vigule, Zane A22

Volkova, Jūlija A22

Voronova, Angelika A18

Voskresenska, Jekaterina A5

Zorenko, Tanya A23 